\title{
PENGARUH PENDIDIKAN MATEMATIKA REALISTIK TERHADAP SUASANA PEMBELAJARAN YANG MENYENANGKAN PADA PELAJARAN MATEMATIKA SEKOLAH DASAR
}

\author{
Prayogo Pangestu ${ }^{1)}$ dan Apri Utami Parta Santi' ${ }^{2)}$ \\ Universitas Muhammadiyah Jakarta \\ 1)prayogo.kimia@gmail.com \\ ${ }^{2)}$ tetivianita@gmail.com
}

\begin{abstract}
Abstrak
Penelitian ini dilatar belakangi oleh hipotesis peneliti yang menduga adanya pengaruh antara pendidikan matematika realistik yang diterapkan guru dengan suasana pembelajaran yang menyenangkan di kelas. Adapun tujuan penelitian ini untuk mengetahui seberapa besar pengaruh Pendidikan Matematika Realistik terhadap suasana pembelajaran yang terjadi di kelas. Penelitian dilaksanakan di SDN Cempaka Putih 01 Ciputat, kota Tangerang Selatan. Metode yang digunakan adalah metode survey dengan menggunakan angket sebagai instrumen pokok. Sampel penelitian yang digunakan dalam penelitian ini adalah kelas IV-B yang berjumlah 31 siswa. Pengambilan sampel menggunakan teknik sampeling jenuh. Instrumen yang diberikan adalah angket dengan pernyataan untuk pendidikan matematika realistik sebanyak 12 pernyataan dan kesenangan belajar siswa sebanyak 15 pernyataan. Analisis data menggunakan korelasi dan regresi sederhana, diperoleh nilai $r_{\text {hitung }}$ sebesar 0,675 , sedangkan $r_{\text {tabel }}$ pada taraf signifikan 0,5 yaitu sebesar 0,355. Maka dapat dikatakan bahwa $\mathrm{r}_{\text {hitung }}>\mathrm{r}_{\text {tabel. }}$. Hal ini menunjukan adanya pengaruh yang kuat antara pendidikan matematika realistik terhadap suasana pembelajaran yang menyenangkan.
\end{abstract}

\section{Kata Kunci:}

\section{PENDAHULUAN}

Pendidikan merupakan suatu kebutuhan yang harus dipenuhi dalam kehidupan bermasyarakat, berbangsa dan bertanah air. Pemerintah telah mencanangkan pendidikan sebagai instrumen untuk membangun bangsa dan negara Indonesia menjadi lebih baik. Sebagaimana tercantum dalam Undang-Undang Republik Indonesia tentang Sistem Pendidikan Nasional No.20 Tahun 2003 pada BAB II pasal 3 bahwa pendidikan nasional berfungsi mengembangkan kemampuan dan bentuk watak serta peradaban bangsa yang bermartabat dalam rangka mencerdaskan bangsa, bertujuan untuk berkembangnya potensi 
Esa, berakhlak mulia, sehat, berilmu, cakap, kreatif, mandiri, dan menjadi warga negara yang demokratis serta bertanggung jawab.

Pembelajaran di sekolah turut andil dalam pencapaian mencerdaskan kehidupan bangsa. Hartono (2010:71) menjelaskan, salah satu mata pelajaran yang memberikan konstribusi positif bagi pencerdasan kehidupan bangsa sekaligus turut memanusiakan bangsa Indonesia dalam arti dan cakupan yang lebih luas adalah mata pelajaran matematika. Berkaitan dengan pembelajaran matematika diharapkan guru mampu meningkatkan kualitas dalam proses pembelajaran, mengingat permasalahan yang umum terjadi di SD adalah kurangnya kesenangan belajar siswa terhadap pembelajaran matematika disekolah. Mereka menganggap bahwa pelajaran matematika itu sulit, hal tersebut diyakini sebagai salah satu penyebab kurangnya ketertarikan siswa terhadap pelajaran matematika. Oleh karena itu, pembelajaran matematika perlu mendapatkan perhatian khusus.

Pada penerapan pembelajaran matematika, guru diharapkan lebih kreatif dalam merancang strategi pembelajaran matematika sehingga lebih bervariasi. Menurut Lidinillah (2006:15), siswa sekolah dasar yang secara psikologi masih dalam tahap operasional konkrit memerlukan pembelajaran yang kontekstual yang memicu peserta didik agar aktif, kreatif, efektif dan menyenangkan (PAKEM) untuk membantu siswa dalam mengkonstruksi pengetahuannya terutama dalam bidang matematika. Pemahaman pada konsep matematika yang kuat yang dihasilkan dari serangkaian pengalaman belajar akan menjadi bekal bagi siswa dalam menempuh jenjang pendidikan selanjutnya.

Menurut Hartono (2010: 73), salah satu strategi pembelajaran kontekstual yaitu dengan pembelajaran matematika realistik merupakan salah satu alternatif untuk mengatasi masalah-masalah dalam pembelajaran matematika tersebut. Pada penerapannya, pendididikan matematika realistik dikemas sebagai proses penemuan kembali terbimbing sehingga peserta didik dapat mengalami proses yang sama dengan proses penemuan ide dan konsep matematika. Proses ini mampu menciptakan suasana yang dapat membangkitkan kemampuan berfikir dan berargumentasi dalam menyelesaikan masalah dengan berbagai ide atau gagasan yang dapat menarik kesenangan bejar siswa terhadap pembelajaran matematika tersebut.

Berdasarkan uraian diatas permasalahan yang dikemukakan dalam penelitian adalah “Apakah pembelajaran matematika realistik dapat meningkatkan kesenangan belajar siswa?". Masalah tersebut dirinci dalam pertanyaan- pertanyaan penelitian berikut:

1. Apakah ada pengaruh pembelajaran matematika realistik dengan kesenangan belajar siswa? 
2. Seberapa besar pengaruh kesenangan belajar siswa dengan menerapkan pembelajaran pembelajaran matematika realistik?

Pendidikan Matematika Realistik merupakan matematika sekolah yang dilaksanakan dengan menempatkan realitas dan pengalaman siswa sebagai titik awal pembelajaran. Pendidikan Matematika Realistik menggunakan masalah realistik sebagai pangkal tolak pembelajaran sehingga siswa diharapkan dapat menemukan dan merekonstruksi konsepkonsep matematika atau pengetahuan matematika formal.

Selanjutnya, siswa diberi kesempatan menerapkan konsep-konsep matematika untuk memecahkan masalah sehari-hari atau masalah dalam bidang lain. Dengan kata lain, pembelajaran matematika realistik berorientasi pada matematisasi pengalaman sehari-hari (mathematize of everyday experience) dan menerapkan matematika dalam kehidupan seharihari (everydaying mathematics), sehingga siswa belajar dengan bermakna (pengertian).

Menurut Suharta dalam Supardi (2012: 245) Pendidikan Matematika Realistik merupakan teori belajar mengajar dalam pendidikan matematika yang harus dikaitkan dengan realita karena matematika merupakan aktivitas manusia. Hal ini berarti matematika harus dekat dengan anak dan relevan dalam kehidupan sehari-hari. Sedangkan Zulkardi 2001 dalam Fitriana 2010: 33) mendefinisikan matematika realistik sebagai berikut : Pendidikan Matematika Realistik adalah teori pembelajaran yang bertitik tolak dari hal-hal 'real' bagi siswa, menekankan keterampilan 'prosess of doing mathematics', berdiskusi dan berkolaborasi, berargumentasi dengan teman sekelas sehingga mereka dapat menemukan sendiri ('student iventing' sebagai kebalikan dari 'teacher telling') dan pada akhirnya menggunakan matematika itu untuk menyelesaikan masalah baik individual maupun kelompok.

Berdasarkan pendapat para ahli tersebut maka dapat disimpulkan bahwa pembelajaran matematika realistik adalah matematika sekolah yang dilaksanakan dengan menempatkan realitas dan pengalaman siswa sebagai titik awal pembelajaran. Adapun tujuan pendidikan matematika realistik ialah: agar siswa dapat mengembangkan keterampilan berdiskusi, berkolaborasi dan berargumentasi dengan teman sekelas sehingga siswa mendapatkan pembelajaran yang bermakna.

Menurut Suherman (dalam Lidinillah, 2006: 9) ada lima prinsip utama dalam pendidikan matematika realistik, yaitu :

1. Didominasi oleh masalah-masalah dalam konteks, melayani dua hal yaitu sebagai sumber dan sebagai serapan konsep matematika; 
2. Perhatian diberikan pada pengembangan model-model, situasi, skema, dan simbolsimbol ;

3. Sumbangan dari para siswa, sehingga siswa dapat membuat pembelajaran menjadi konstruktif dan produktif, artinya siswa mengkonstruksi sendiri, sehingga dapat membimbing siswa dari level matematika informal menuju matematika formal;

4. Interaktif sebagai karakteristik dari proses pembelajaran matematika; dan

5. Intertwining (membuat jalinan) jalinar antar topik atau antar pokok bahasan.

Menurut Hobri (dalam Ningsih, 2014: 82) langkah-langkah dalam kegiatan inti proses pendidikan matematika realistik pada penelitian ini adalah:

1. Memahami masalah kontekstual

Guru memberikan masalah kontekstual dan siswa memahami permasalahan tersebut.

2. Menjelaskan masalah kontekstual

Guru menjelaskan situasi dan kondisi soal dengan memberikan petunjuk/saran seperlunya (terbatas) terhadap bagian-bagian tertentu yang belum dipahami siswa. Penjelasan ini hanya sampai siswa mengerti maksud soal.

3. Menyelesaikan masalah kontekstual

Siswa secara individu menyelesaikan masalah kontekstual dengan cara mereka sendiri. Guru memotivasi siswa untuk menyelesaikan masalah dengan cara mereka dengan memberikan pertanyaan / petunjuk /saran.

4. Membandingkan dan mendiskusikan jawaban

Guru menyediakan waktu dan kesempatan pada siswa untuk membandingkan dan mendiskusikan jawaban dari soal secara berkelompok. Untuk selanjutnya dibandingkan dan didiskusikan pada diskusi kelas.

5. Menyimpulkan

Dari diskusi, guru mengarahkan siswa menarik kesimpulan suatu prosedur atau konsep, dengan guru bertindak sebagai pembimbing.

Dalam penerapannya matematika realistik dapat meningkatkan kesenangan belajar siswa karena pada pendidikan matematika realistik membahas masalah-masalah kontekstual sehingga siswa turut aktif dalam pembelajaran tersebut. Menurut Asmani (2012: 93) ada beberapa ciri-ciri pembelajaran yang menyenangkan, yaitu:

1. Kegiatan pembelajaran menarik, menantang, dan meningkatkan motivasi. 
Pada pembelajaran yang menyenangkan, siswa diharapkan dapat tertarik, tertantang serta dapat meningkatkan motivasi agar siswa berani mengemukakan pendapat dalam pembelajaran. Adanya kegiatan-kegiatan tersebut, suasana pembelajaran menjadi lebih hidup, sehingga tercipta komunikasi yang baik antara siswa dengan siswa maupun siswa dengan guru.

2. Mendapat pengalaman secara langsung

Pembelajaran yang menyenangkan dapat memotivasi siswa dalam belajar, sehingga siswa aktif dalam pembelajaran. Ketika siswa telah termotivasi dan aktif dalam belajar, maka siswa akan membangun sendiri pengalaman belajarnya tanpa harus diberikan instruksi oleh guru, dengan demikian siswa secara tidak langsung siswa mengembangkan sendiri potensi dalam dirinya sehingga pembelajaran lebih bermakna.

3. Kemampuan berpikir kritis dalam memecahkan masalah semakin meningkat.

Kesenangan belajar siswa akan memberikan dampak positif pada keaktifan belajar siswa, salah satunya adalah peningkatan kemampuan berpikir kritis dalam memecahkan masalah. Adanya keaktifan belajar, siswa akan terpicu untuk memecahkan masalah. Masalah-masalah yang dipecahkan oleh siswa akan menjadikan tingkat berpikir siswa meningkat.

4. Tidak membuat siswa takut

Pembelajaran yang didasarkan dengan kesenangan siswa, tidak akan membuat siswa tertekan dan takut, sebaliknya siswa akan merasa nyaman dan berani mencoba/berbuat, berani bertanya, berani memberikan gagasan/pendapat, berani mempertanyakan gagasan orang lain.

Menurut Idris (2014 : 71) ada beberapa langkah dalam menerapkan pembelajaran yang menyenangkan :

1. Menciptakan iklim yang nyaman untuk peserta didik

Pada pembelajaran yang menyenangkan, langkah pertama yang dilakukan oleh guru adalah menciptakan iklim yang nyaman untuk peserta didik agar mereka dapat menyerap pelajaran secara maksimal. Adapun menciptakan pembelajaran yang nyaman dapat dilakukan dengan cara: mengatur posisi duduk memakai format $\mathrm{U}$, lingkaran, Cevron, dan lain-lain., menanamkan keberanian siswa dalam mengemukakan pertanyaan atau menjawab pertanyaan, memberi maind set kepada peserta didik bahwa kesalahan dalam belajar adalah suatu yang lumrah dan tidak berdosa.

2. Memberi pertanyaan yang mudah dijawab 
Untuk merangsang minat belajar peserta didik, maka guru hendaknya memberi pertanyaan yang mudah dijawab agar peserta didik lebih termotivasi lagi untuk menjawab soal yang lebih sulit. Setelah siswa menjawab soal dengan benar, guru memberikan pujian agar peserta didik lebih termotivasi lagi. Dengan demikian, pembelajaran yang menyenangkan dapat tercipta dengan baik.

3. Siswa mengetahui pelajaran sebelum kelas dimulai

Sebelum kelas dimulai, guru meminta peserta didik agar mempelajari bahan yang nantinya akan ditanyakan. Sehingga, mereka akan mempersiapkannya terlebih dahulu. Hal ini bertujuan agar siswa menjadi lebih nyaman dan tidak ragu-ragu ataupun takut ketika menjawab pertanyaan yang diajukan oleh guru.

4. Mengontrol siswa dengan alat kontrol.

Selama pembelajaran berlangsung, dalam pembelajaran yang menyenangkan salah satu peran guru adalah mengkontrol siswa dengan alat control. Hal ini bertujuan agar guru dapat memantau perkembangan peserta didik setelah dilakukannya proses pembelajaran. Alat control bisa berupa wawancara, angket ataupun pretest ataupun post test.

\section{METODE PENELITIAN}

Penelitian ini dilaksanakan di kelas IV SD Negeri Cempaka Putih 1 Tangerang Selatan pada mata pelajaran matematika. Penelitian dilaksanakan pada awal bulan Mei 2016 sampai dengan akhir bulan Juli 2016. Adapun Subjek penelitian dalam penelitian ini adalah siswa kelas IV SD Negeri Cempaka Putih 1 tahun ajaran 2015/2016 yang berjumlah 67 siswa (2 kelas). Akan tetapi, peneliti hanya meneliti kelas IV B sebagai objek penelitian dengan jumlah populasi sebanyak 34 siswa.

Teknik pengambilan sampel dalam penelitian ini menggunakan sampling jenuh. Menurut Supriyadi sampeling jenuh yaitu sampel yang mewakili jumlah populasi. Biasanya dilakukan jika populasi dianggap kecil atau kurang dari 100, istilah lain disebutnya total sampling. Pada penelitian ini peneliti mengambil sampel kelas IV B.

Penelitian ini menggunakan metode survey. Menurut Sofian dan Tukiran (2012 : 3) metode penelitian survei adalah penelitian yang mengambil sampel dari satu populasi dan menggunakan kuisioner sebagai alat pengumpulan data yang pokok. Sedangkan untuk data yang dikumpulkan peneliti menggunakan jenis penelitian kuantitatif. 


\section{HASIL DAN PEMBAHASAN}

Uji Validitas dan Reabilitas

Uji validitas dan reliabitas angket dalam penelitian ini menggunakan jasa program yang bernama Statistical Package for the Social Solencers (SPSS). Uji validitas atau kesahihan item instrument dalam penelitian ini menghasilkan item valid dan gugur dengan kriteria validitas 0,5 maka dikatakan valid. Uji Validitas dilakukan di kelas IV-B SDN Cempaka Putih 01 dari uji tersebut terdapat beberapa item yang valid dan gugur. Berikut daftar item yang valid dan gugur dalam uji coba instrumen.

Tabel 1. Hasil Uji Validitas Pengaruh Pendidikan Matematika Realistik Terhadap Suasana Pembelajaran Yang Menyenangkan

\begin{tabular}{|c|c|c|c|}
\hline \multirow[t]{2}{*}{ No } & \multirow[t]{2}{*}{ Aspek } & \multicolumn{2}{|l|}{ Item } \\
\hline & & Valid & Gugur \\
\hline $\mathbf{1}$ & $\begin{array}{l}\text { Pendidikan } \\
\text { Realistik }\end{array}$ & $\begin{array}{l}1,4,5,6,7,8,9,10,11,12,13, \\
14\end{array}$ & 2,3 \\
\hline 2 & $\begin{array}{l}\text { Suasana Pembelajaran } \\
\text { Yang menyenangkan }\end{array}$ & $\begin{array}{l}2,3,6,9,10,11,12,13,15,16 \\
17,18,19,21,22\end{array}$ & $2,4,5,7,8,14,20$ \\
\hline
\end{tabular}

Berdasarkan Tabel di atas maka hasil uji validitas skala Pendidikan matematika realistik yang diuji cobakan pada kelas IV-B yang berjumlah 32 responden total item 12 karena 2 item tidak valid dan hasil uji valliditas skala suasana pembelajaran yang menyenangkan diuji cobakan pada kelas IV-B yang berjumlah 32 responden total item 15 karena 7 item tidak valid. Dengan $r$ tabel adalah 0,300. Dikatakan valid jika $r$ hitung $>r$ tabel.

Adapun uji reliabilitas yakni derajat kepercayaan yang diperoleh dari hasil angket sebagai metode pengumpulan data yakni menggunakan kriteria 0,128 maka disebut reliabel. Berdasarkan perhitungan dengan rumus alpha cronbach menggunakan Statistical Package for the Social Solencers (SPSS) didapatkan data sebagai berikut:

Tabel 2. Reliabilitas Variabel X Reliability Statistics

\begin{tabular}{|l|l|}
\hline Cronbach's Alpha & N of Items \\
\hline 770 & 12 \\
\hline
\end{tabular}

Tabel 3. Rerliabilitas variabel $Y$ Reliability Statistics

\begin{tabular}{|l|l|}
\hline Cronbach's Alpha & $\mathrm{N}$ of Items \\
\hline 803 & 15 \\
\hline
\end{tabular}


Skala pembelajaran matematika realistik dan kesenangan belajar matematika ini memiliki derajat reliabilitas sebesar 0,770 dan 0,803 . Hal ini berarti instrumen yang digunakan peneliti dalam pengumpulan data cukup dapat dipercaya sebagai alat pengumpul data.

\section{$\underline{\text { Uji Normalitas Data }}$}

Uji normalitas pada penelitian ini adalah menggunakan uji Kolmogorov-Smirnov, pada taraf signifikan $(\alpha=0,05)$ dan banyaknya sampel 32 siswa. Berdasarkan hasil perhitungan maka didapatkan data sebagai berikut:

\section{Tabel 4. Normalitas Data}

\section{Tests of Normality}

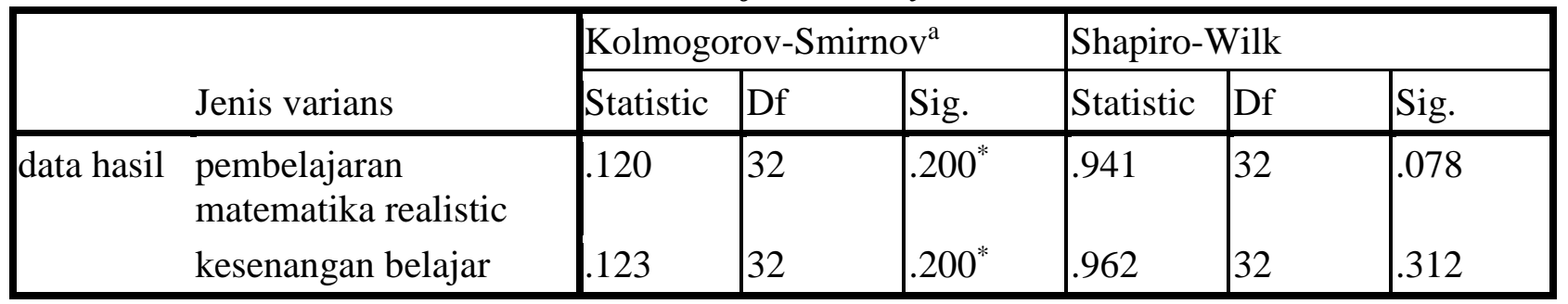

a. Lilliefors Significance Correction

*. This is a lower bound of the true significance.

Berdasarkan data di atas dapat disimpulkan bahwa $r$ hitung $<\mathrm{r}$ tabel $(0,242)$. Hal ini terbukti pada perhitungan SPSS 17 dengan nilai signifikan variabel X (Pembelajaran Matematika Realistik) dan Y (Kesenangan Belajar Matematika) yang diperoleh sebesar 0,200 dan 0,200 . Sehingga $r$ hitung variabel $X(0,200)<r$ tabel $(0,242)$ dan $r$ hitung variabel $Y$ $(0,200)<\mathrm{r}$ tabel $(0,242)$ yang berarti kedua data berdistribusi normal.

\section{$\underline{\text { Analisis Korelasi Sederhana }}$}

Penelitian ini menggunakan teknik pengumpul data untuk memperoleh data, yaitu angket. Dalam pengambilan data, penulis terlebih dahulu melakukan penyebaran angket yang didalamnya berisi pernyataan-pernyataan tentang pembelajaran matematika realistik dan kesenangan belajar matematika siswa kelas IV-B. Setelah itu data ditabulasikan untuk selanjutnya dihitung dalam bentuk persentase. Langkah selanjutnya adalah menganalisa, mengintegretasi data yang diperoleh, mencari untuk mengetahui seberapa besar kontribusi variabel $\mathrm{X}$ terhadap variabel $\mathrm{Y}$. 
Data tentang pembelajaran matematika realistik sebagai variabel $\mathrm{X}$ dan kesenangan belajar matematika sebagai variabel Y yang diperoleh berdasarkan penyebaran angket pada 32 responden yaitu

kelas IV-B SDN Cempaka Putih 01 dengan menggunakan rumus product moment sebagai berikut:

$$
\begin{aligned}
\mathrm{RXY}= & \frac{n\left(\sum X Y\right)-\left(\sum X\right) \cdot\left(\sum Y\right)}{\sqrt{\left\{n \cdot \sum X^{2}-\left(\sum X\right)^{2}\right\} \cdot\left\{n \cdot \sum Y^{2}-\left(\sum Y\right)^{2}\right\}}} \\
& =\frac{31(97286)-(1544)(1934)}{\sqrt{\left(31 \cdot(78374)-(1544)^{2}\right\} \cdot\left(31 \cdot(122030)-(1934)^{2}\right\}}} \\
& =\frac{3015866-2986096}{\sqrt{(2429594-2383936) \cdot(3782930-3740356)}} \\
& =\frac{29770}{\sqrt{(45658) \cdot(42574)}} \\
& =\frac{29770}{\sqrt{1943843692}} \\
& =\frac{29770}{44089,04} \\
& =0,675
\end{aligned}
$$

Dari tabel perhitungan rumus product moment di atas dapat diketahui hasil korelasi antara variabel X (Pembelajaran Matematika Realistik) dan variabel Y (Kesenangan Belajar Matematika) adalah rxy 0,675. Dengan mendapat besarnya rxy (yaitu: 0,675), yang berkisar antara $0,400-0,599$ berarti antara variabel $\mathrm{X}$ dan $\mathrm{Y}$ terdapat korelasi yang cukup tinggi.

\section{$\underline{\text { Penentuan Koefisien Determinasi }}$}

Adapun perhitungan koefisien Determinasi (KD) yang penulis manfaatkan untuk mengetahui kontribusi variabel $\mathrm{X}$ terhadap variabel Y. sebagai berikut:

$$
\begin{aligned}
\mathrm{KD} & =r^{2} \times 100 \% \\
& =(0,675)^{2} \times 100 \% \\
& =46_{2}, 6 \%
\end{aligned}
$$

Artinya variabel pembelajaran matematika realistik memberikan kontribusi terhadap kesenangan belajar matematika sebesar $45,6 \%$. 


\section{$\underline{\text { Regresi Linear Sederhana }}$}

Tabel 5. Variables Entered/Removed ${ }^{b}$

\begin{tabular}{|l|l|l|l|}
\hline Model & $\begin{array}{l}\text { Variables } \\
\text { Entered }\end{array}$ & $\begin{array}{l}\text { Variables } \\
\text { Removed }\end{array}$ & Method \\
\hline 1 & $\mathrm{X}^{\mathrm{a}}$ &. & Enter \\
\hline
\end{tabular}

a. All requested variables entered.

b. Dependen Variable: $Y$

Tabel di atas menjelaskan tentang variabel yang dimasukkan atau dibuang dan metode yang digunakan. Dalam hal ini variabel yang dimasukkan adalah variabel nilai $\mathrm{X}$ (Pembelajaran Matematika Realistik) sebagai predictor dan metode yang digunakan adalah metode enter.

Tabel 6. Model Summary

\begin{tabular}{|l|l|l|l|l|}
\hline Model & $\mathrm{R}$ & R Square & Adjusted R Square & Std. Error of the Estimate \\
\hline 1 & $.675^{\mathrm{a}}$ & .456 & .437 & 5.076 \\
\hline
\end{tabular}

a. Predictors: (Constant), $X$

Tabel di atas menjelaskan besarnya nilai korelasi/hubungan (R) yaitu sebesar 0.675 dan dijelaskan besarnya presentase pengaruh variabel bebas terhadap variabel terikat disebut koefisien determinasi yang merupakan hasil dari peguadratan R. Dari output tersebut diperoleh Koefisien Determinasi $\left(\mathrm{R}^{2}\right)$ sebesar 0,456, yang mengandung pengertian bahwa pengaruh variabel bebas (Y) terhadap variabel terikat $(\mathrm{X})$ adalah sebesar 45,6\%, sedangkan sisanya dipengaruhi oleh variabel yang lain.

Tabel 7. ANOVA ${ }^{\mathrm{b}}$

\begin{tabular}{|l|r|r|r|c|c|}
\hline Model & Sum of Squares & df & Mean Square & F & Sig. \\
\hline 1 Regression & 626.151 & 1 & 626.151 & 24.302 & $.000^{\mathrm{a}}$ \\
Residual & 747.204 & 29 & 25.766 & & \\
Total & 1373.355 & 30 & & & \\
\hline
\end{tabular}

a. Predictors: (Constant), $X$

b. Dependent Variable: Y

Pada bagian ini menjelaskan apakah ada pengaruh nyata (signifikan) variabel $\mathrm{X}$ (Pembelajaran Matematika Realistik) terhadap variabel Y (Kesenangan Belajar Matematika). Dari output tersebut terlihat bahwa $\mathrm{F}$ hitung $=24,302$ dengan tingkat signifikansi/ probabilitas $0,000<0,05$, maka model regresi dapat dipakai untuk memprediksi variabel kesenangan belajar siswa. 
Tabel 8. Coefficients ${ }^{\mathrm{a}}$

\begin{tabular}{|l|l|l|l|l|l|}
\hline \multirow{2}{*}{ Model } & \multicolumn{2}{|l|}{$\begin{array}{l}\text { Unstandardized } \\
\text { Coefficients }\end{array}$} & $\begin{array}{l}\text { Standardized } \\
\text { Coefficients }\end{array}$ & & \\
\cline { 2 - 5 } & $\mathrm{B}$ & Std. Error & Beta & $\mathrm{t}$ & Sig. \\
\hline 1 (Constant) & 29.912 & 6.650 & & 4.498 & .000 \\
$\mathrm{X}$ & .652 & .132 & .675 & 4.930 & .000 \\
\hline
\end{tabular}

a. Dependent Variable: $Y$

Pada tabel Coefficients, pada kolom B (a) adalah 29,481, sedang nilai bX adalah 0,652 , sehingga persamaan regresinya dapat ditulis:

$$
\mathrm{Y}=\mathrm{a}+\mathrm{bX} \text { atau } 29,481+0,652
$$

Koefisien b dinamakan koefisien arah regresi dan menyatakan perubahan rata-rata variabel Y untuk setiap perubahan variabel X sebesar satu satuan. Perubahan ini merupakan pertambahan bila $\mathrm{b}$ bertanda positif dan penurunan bila $\mathrm{b}$ bertanda negatif. Sehingga persamaan tersebut dapat diterjemahkan:

1. Konstanta sebesar 29,912 menyatakan bahwa tidak ada nilai $\mathrm{X}$ maka nilai $\mathrm{Y}$ sebesar 29,912

2. Koefisien regresi $X$ sebesar 0,652 menyatakan bahwa setiap penambahan 1 nilai $X$, maka nilai nilai Y bertambah besar 0,652

Berdasarkan hal tersebut dapat disimpulkan

Ho : tidak ada pengaruh antara variabel X (Pembelajaran Matematika Realistik terhadap Variabel Y (Kesenangan belajar Matematika)

$\mathrm{H}_{\mathrm{a}}$ : ada pengaruh antara variabel $\mathrm{X}$ (Pembelajaran Matematika Realistik terhadap Variabel Y (Kesenangan belajar Matematika)

Dari output diatas dapat diketahui t hitung $=4,930$ dengan nilai signifikansi $0,000<0,05$, maka Ho ditolak dan $\mathrm{H}_{\mathrm{a}}$ diterima, berarti ada pengaruh antara variabel X (Pembelajaran Matematika Realistik terhadap Variabel Y (Kesenangan belajar Matematika).

\section{Interpretasi Hasil Penelitian}

Berdasarkan hasil perhitungan dari nilai "rxy", maka penulis memberikan interpretasi terhadap angka indeks korelasi r product moment yakni:

1. Interpretasi dengan cara sederhana atau secara kasar

Interpretasi terhadap rxy dari perhitungan diatas ternyata angka korelasi antara variabel X (pembelajaran matematika realistik) dan variabel Y (Kesenangan belajar matematika) 
tidak bertanda negative. Berarti diantara kedua variabel tersebut terhadap korelasi positif (korelasi yang berjalan searah). Dengan mendapat besarnya rxy (yaitu: 0,675), yang berkisar antara $0,400-0,599$ berarti antara variabel $\mathrm{X}$ dan $\mathrm{Y}$ terdapat korelasi yang cukup tinggi.

2. Interpretasi dengan menggunakan tabel nilai " $r$ " product moment

Rumusan Hipotesa Alternatif (Ha) dan hipotesa nihil (Ho), yang penulis ajukan diawal ialah:

Ha : Terdapat pengaruh yang signifikan antara pembelajaran matematika realistik terhadap kesenangan belajar matematika.

Ho : Tidak ada pengaruh yang signifikan antara pembelajaran matematika realistic terhadap kesenangan belajar matematika.

Adapun kriteria pengajuannya adalah: jika $r$ hitung $>r$ tabel maka Ha diterima dan Ho ditolak. Sebaliknya, jika $r$ hitung < dari pada $r$ tabel maka Ha ditolak dan untuk melihat apakah koefisien korelasi hasil perhitungan diatas signifikan atau ditolak, maka perlu dibandingkan dengan $\mathrm{r}$ tabel (rt) product moment dengan terlebih dahulu mencari derajat bebas (df). Karna dalam penelitian ini 32 siswa dan variabel yang dicari korelasinya dua yaitu pembelajaran matematika realistik dan kesenangan belajar siswa, maka derajat bebasnya dapat dihitung dengan langkah sebagai berikut:

$$
\begin{aligned}
\text { Df } & =\mathrm{N}-2 \\
& =31-2 \\
& =29
\end{aligned}
$$

Keterangan :

$\mathrm{N}$ : Jumlah responden

$\mathrm{r}$ : Jumlah variabel yang diteliti

Setelah diketahui Df sebesar 29, maka diperoleh "r" product moment dengan memeriksa tabel " $r$ " product moment ternyata dengan Df sebesar 29 dan taraf signifikansi 5\% dari df diperoleh $r_{\text {tabel }}=0,367$, karna $r_{\text {tabel }}$ pada taraf signifikansi 5\% lebih kecil dari rxy $(0,367<0,675)$, maka pada taraf signifikansi 5\% Ha diterima sedangkan Ho ditolak. Berarti bahwa taraf signifikansi $5 \%$ terdapat korelasi signifikan antara variabel $\mathrm{X}$ dan variabel $\mathrm{Y}$. Berdasarkan uraian tersebut dapat disimpulkan bahwa pembelajaran matematika realistik berpengaruh terhadap kesenangan belajar matematika siswa di SDN Cempaka Putih 01. 


\section{SIMPULAN}

Dari uraian penelitian yang sudah telah dilaksanakan, maka peneliti dapat simpulkan sebagai berikut :

Pengaruh pembelajaran matematika realistik terhadap kesenangan belajar siswa kelas IV SDN Cempaka Putih 01 Ciputat terdapat korelasi yang cukup tinggi. Hal ini dibuktikan dengan hasil korelasi sebesar 0,675 dengan perbandingan rtabel product moment pada taraf signifikan $5 \%$ yaitu $(0,367<0,675)$. Artinya pembelajaran matematika realistik di SDN Cempaka Putih 01 Pagi memiliki pengaruh yang cukup tinggi terhadap kesenangan belajar matematika. Kesenangan belajar matematika siswa di Sekolah Dasar Negeri Cempaka putih 01 memiliki nilai $45,6 \%$ yang artinya pengaruhnya cukup tinggi. Jadi dari hasil penelitian disimpulkan pembelajaran matematika realistik berpengaruh terhadap kesenangan belajar matematika siswa di Sekolah Dasar Negeri Cempaka Putih 01 Ciputat.

\section{DAFTAR PUSTAKA}

Asmani, Jamal ma'mur. (2012). 7 Tips Aplikasi PAKEM. Jogyakarta: Diva Press.

Abduh, Muhammad. (2010). Menciptakan Pembelajaran Yang Menyenangkan. Jakarta: Universitas Terbuka.

Effendi, Tukiran dan Sofyan. (2012). Metode Penelitian Survei. Jakarta: LP3ES.

Fitriana, Hanny. (2010). Pengaruh Pendidikan Matematika Realistik Kemampuan Pemecahan Masalah Siswa. Skripsi, UIN Syarif Hidayatullah Jakarta

Hamzah, Ali. (2014). Perencanaan Dan Strategi Pembelajaran Matematika. Jakarta: Rajawali Press.

Hartono, Yusuf. (2010). Pembelajaran Matematika Sekolah Dasar. Jakarta: Universitas Terbuka.

H.Idris, Metty H. (2014). Strategi Pembelajaran Yang Menyenangkan. Jakarta: Luxima Metro Media.

Lidinillah, Muiz. (2006). Strategi Pembelajaran Matematika di Sekolah Dasar. Tasikmalaya: Kampus Tasikmalaya.

Ningsih, Seri. (2014). "Realistic Mathematics Education: Model Alternatif Pembelajaran Matematika Sekolah”. JPM IAIN Antasari. Vol.2 (2).

Rasyad, Amiuddin. (2010). Teori Belajar dan Pembelajaran. Jakarta: UHAMKA PRESS.

Riduwan. (2010). Belajar Mudah Penelitian Untuk Guru -Karyawan dan Peneliti Pemula. Bandung: Alfabeta.

Republik Indonesia. (2003). Undang-undang Sistem Pendidikan Nasional. Jakarta: Sekertariat Negara. 
Siregar, Syofian. (2013). Metode Penelitian Kuantitatif: Dilengkapi Perbandingan Perhitungan Manual \& SPSS. Jakarta: Kencana.

Slameto. (2010). Belajar dan Faktor-Faktor yang Mempengaruhi. Jakarta Rineka Cipta.

Supardi U.S. (2012). Pembelajaran Matematika Realistik Terhadap Hasil Belajar Matematika Ditinjau Dari Motivasi Belajar. Jakarta: Universitas Indraprasta PGRI Jakarta.

Sugiyono. (2011). Metode Penelitian Kuantitatif, Kualitatif, dan R\&D. Jakarta: Alfabeta.

Supriyadi, Edy. (2014). SPSS + Amos. Jakarta: In Media.

Windayana, Husen. (2007). "Pembelajaran Matematika Realistik Dalam Meningkatkan Berpikir Logis, Kreatif, dan Kritis, Serta Komunikasi Siswa Sekolah Dasar”. Jurnal Pendidikan Dasar. No.8. 